\title{
sciendo
}

DOI: 10.2478/jolace-2021-0006

\section{Teaching degree students' experience of teaching practice}

\author{
Adriana Wiegerová, Hana Lukášová \\ Tomas Bata University in Zlín, the Czech Republic \\ wiegerova@utb.cz
}

\begin{abstract}
The study is focussed on perception of teaching practices by pre-service teachers in preschool and primary education university programmes. Further, the study analysed the reality shock that occurred in these students during teaching practice. The sample consisted of 41 students in preschool education programmes, while 54 students followed the primary-level education programme. The data collection methods were student portfolios and student diaries from teaching practice. In the portfolios it was possible to analyse the activities, opinions, attitudes and products of student practice. Diaries reported students' feelings and everyday experience in the schools. Qualitative content analysis was used to analyse the data. Two significant findings were obtained, i.e., supervising teachers' frequent unprofessional behaviour towards student teachers, and the somatic and emotional exhaustion of students.

Key words: professional identity, starting identity, student preparation, reflective portfolio, student diary, starting profession, teaching practice, students' experience of practice
\end{abstract}

\section{Introduction}

The objective of this study is to inform readers of an approach to analysing the professional preparation of future teachers at one non-education faculty in the Czech Republic. This paper does not aim to support the large number of studies which demonstrate the positive aspects of teaching practice implementation. The authors are aware of the strength of these arguments and are also convinced of the importance of teaching practice in the context of preparing future teachers. And because practice has continued to improve and has enabled the gradual implementation of a path towards professional identity, it is beneficial to also note situations experienced by current students - future preschool and elementary school teachers - which are not commonly discussed in studies of a similar nature. The objective of the submitted work is therefore merely to draw attention to problematic aspects of teaching practice and the need to reflect students' experiences.

In the Czech Republic, teaching degree curricula are structured so that teaching practice holds a precise weight in terms of numbers of credits attained. In general, practice is divided up into observational, continuous and intensive practice. Observational practice is done to get acquainted with the school environment, as well as classes or groups. Continuous practice is undertaken over the course of the entire second and third year of non-graduate study and is linked to students' first endeavours at producing their own outputs. Intensive practice occurs in the final year of studies and lasts from four to six weeks. Our research was mainly focused on continuous practice. Within Czech university curricula, practice is implemented within so-called "faculty schools", which have signed an agreement with the particular university in this regard.

We can understand experience as an internal processing of perceived situations and events, especially with an emotional dimension. It is highly individual, subjective and gives one meaning and significance. Czech differentiates between two types of experience: prožívaní which is described above, and zkušenost, which does not involve the emotional 
aspect described above. Phenomenology utilises the concept of "lived experience" (Bunnin, 2004; Lindseth, \& Norberg, 2004) in the former context. This involves a person subjecting perceived situations and events to subjective interpretation. This lived experience can produce a wide range of emotions - from very pleasant to markedly unpleasant. In this study, as mentioned above, we are focusing on the lived experience which has aroused unpleasant feelings in students undertaking teaching practice.

Many academic papers have been written on the subject of teaching practice within Czech discourse (e.g. Spilková, Tomková, Mazáčová, Kargerová et al., 2015, Janík, 2002). The starting point for the support of professional identity, or its initial phases, i.e. the starting identity for future teachers, is continuous searching, co-operation between participating academic workers and teachers from practice. The core of an approach to professional identity involves the conscious reflection of developing and subjective concepts of teaching, concepts of pupils and self-conception (Mareš et al., 1996). According to Spilková (2004), the professional identity of a future teacher has three basic phases: a starting identity, a transformed identity, and then the resulting professional identity. Pedagogical works of recent years have spoken of how students and also newlyqualified teachers adopt their professional identity, how it is formed and what limits it, or nurtures it (Dicke, 2015, Kim, \& Cho, 2012, Švaříček, 2011, Wiegerová, \& Gavora, 2014).

The construction of a professional identity is a life-long, continuous process. In childhood, in the first phase, it can manifest itself in one's preconceptions of a teacher (Gavora, 2002). A teacher's professional identity is influenced and shaped by their social environment. Future teachers adopt standards and values, and socialise interactively. They are influenced by external stimuli within the school as well as their own internal factors, personal identity, characteristics and skills. They are also constructed on the basis of their own experiences and abilities. The core condition for developing a professional identity is self-knowledge, self-identification, and so also how an individual experiences a situation they find themselves in, and also how this influences them. The development of a professional identity is also influenced by society's approach to the profession of teaching. The changing system of education and teaching, and new European curricular documents are transforming the function and objectives of education policy within European countries. For preschool and elementary schools, professional security is important, creating the foundations for a teacher's professional growth (Spilková, 2010). This already manifests itself during study. Professional security is supported when the personal experiences of the student over the course of teaching practice are reflected in an appropriate manner.

\section{Research survey methodology}

The research objective was to ascertain what students of teaching for preschool and students of teaching at primary level experience personally during their (continuous) practice, and describe how the situation supports their starting identity. A secondary objective was also to monitor the short-term occurrence of reality shock following students beginning practice (described, for example by Dicke et al., 2015, and Stokking et al., 2003).

The research sample comprised a total of 95 student participants. Of these, 54 were students of teaching for primary level (including one man) in the second and third year of their studies, and 41 participants were studying teaching for preschool in their second and third years. The students of teaching for preschool had completed their continuous and intensive teaching practice at preschools, during which they undertook educational activities in classes which were heterogeneous under the management of a faculty 
teacher. Students of primary level teaching had completed their continuous practice in Year 1, Year 2 and Year 3 of elementary school. Data collection was undertaken in two phases. The first was done prior to students beginning their teaching practice. This mainly involved ascertaining their ideas of practice (in a diary), and also mapping their preparation for practice in a professional portfolio. The second phase took place during the period of their teaching practice.

Students' teaching practice was done in two faculty preschools and two faculty elementary schools in 2016 - 2018. Over the period of their studies, all participants completed a number of types of teaching practice from the first year of their studies at university (see Wiegerová, 2015). This study analyses only the experiences during the period of the students' continuous practice. Research participants grew within a specific academic environment, but also within the employment environment represented by the selected preschools and elementary schools. Although at the start of research the objective had been merely to follow what situations the students were experiencing and how they dealt with these personally, over the course of the research (in the context of the tradition of qualitative design), the need to expand the field of research in order also to capture how participants perceive the operation of preschool or elementary schools including as a potential employers became apparent.

Research methods. The main data collection methods were student portfolios and student diaries from teaching practice. The portfolios could be used to monitor the set of activities, opinions, positions and products of student activities. The diaries contained records of feelings, the experience of every day in the preschool or elementary school, and open descriptions of situations experienced. The research did not aim to specifically determine differences between preschool and elementary schools, although these institutes are clearly not the same. It was not important for student experiences whether they were in a preschool or elementary school. What was important was that it was a school in general. Students were instructed to write regularly in their diaries, if possible every day. The size of entries was not limited.

The basis for data analysis in processing the portfolios and diaries was recursive reading. During repeated reading of passages from the portfolios and diaries, it was possible to gradually penetrate the thoughts and feelings of research participants. Sensitive areas were identified during the reading and analysis of portfolios and diaries which conveyed emotionally-charged information from the participant. These segments were labelled and coded. These segments varied in length, though they were never just one word. The codes were systemised and grouped according to meaning. Putting codes into groups produced categories which were able to integrate the codes of that particular group within themselves. Following the production of categories, codes were reevaluated, checked and returned to the categories, meaning there was constant comparison. Thus in processing the qualitative data, an induction principle was applied. The advantage of this principle is that it allows for the production of potentially new perspectives on the investigated phenomenon or phenomena. This gradually led to the production of meaning categories, and relationships between these were revealed. A triangulation of approach was secured with so-called collegial coding (Wiegerová, 2016), meaning that it wasn't just the researchers doing the coding, but also research assistants - i.e. students as student scientific workforce.

The testimony of research participants are indicated in italics within the text. The letters $\mathrm{S} / \mathrm{Z}$ designate the student within the particular study group, while $\mathrm{O}$ or $\mathrm{Q}$ indicates the type of school, and the number of the number of the student used in the data processing. 


\section{Interpreting research findings}

Pedagogical research, as has already been noted, has collected extensive data on the teaching practice of future teachers. However, less research is focused on students' resilience and students own experiences of teaching practice, and there are not many studies investigating this to the present day. Neither are the experience of contacts with students from the perspective of faculty teachers and vice-versa analysed.

The findings the authors have ascertained through data interpretation are far from complete, and they cannot bring answers to all gaps in the preparation of future teachers. The presented research findings, however, represent a contribution towards discussion on improving teaching practice at universities.

\section{1 How it will turn out, or worries about the faculty teacher and parents}

Theoretical and research studies have looked at to what extent students experience social, cultural and educational problems (Clinciu, 2013, pp. 718-722), how universities respond to students' needs (Feld et al. 2011, pp. 44-92) and what specific steps lead to their adaptation (Chang et al., 2007, pp. 135-144). Adaptation to school conditions is a subject of many studies.

Students starting out within faculty school environments feel worries. The new environment may be a source of various situations which may cause difficulties. Adaptation, or the teaching degree students' ability to adapt to the school environment, is an important factor which has an impact on the student's starting identity within the profession. Is school the place where I want to be? Will I be capable of playing my employee role in school? Can I manage it? These are the questions which students posit before teaching practice, and also after completing this practice. The more difficult the conditions in the environment they end up in, the greater the justification for regulating the adaptation process. Students were not in their selected preschool and elementary schools for the first time. They knew the schools, because all their previous practices had been spent at these institutions. For all types of practice, the faculty only co-operates with selected faculty schools. Nevertheless, students' first day doing teaching practice was still accompanied by various emotions.

I was worried about going to preschool. I didn't know how the teacher would accept me, and if we would "click". I knew her, but you never know... (SQ12)

I was most worried about the parents, or rather I was afraid of meeting them. (SO4)

From the responses given, it is clear that students were mainly worried about cooperating with the faculty teacher, and also with parents. These possible areas of conflict are predictable. These fears can be dealt with during the course of preparations for practice at the university, or intervention programmes can be used to support students' adaptability to their new conditions. Worries about meeting parents and faculty teachers were seen both for preschool and primary level schools and were the most mentioned amongst research participants. In this regard, one could boost subjects focused on teachers' professional communication with adults, or with institutions which students shall encounter in their employment, within teaching degree subjects, although faculties perceive these problems as vicarious, i.e., problems which are not part of the core of preparation for teachers. Although curricula do contain courses looking at co-operation with the family, it appears that students also need management in actual communication with parents over the course of their teaching practice. Communication with other 
institutions (such as various centres of support) is represented within teaching curricula somewhat symbolically.

As stated above, students' worries about their teaching practice were in regard to communication with parents and faculty teachers, and it was clear from their responses that students were also worried about their own failures, and shortcomings in their didactic skills.

When I started, I thought that planning one teaching period would not be a problem, but I'm very surprised by the troubles it gives me. (Z2)

When the course of my activities were not even close to my ideas, my feelings from my first teaching experience were not very positive.(Z31)

The first experience of teaching practice is a source of students' own reflection, and this can be motivating for further experiences (see also Korthagen et al., 2011), but where the student is not given adequate assistance, it can also be a source of unpleasant feelings which may give rise to further problems.

Although over the course of their study, students have many opportunities to work on their knowledge and deepen their didactic skills, it has been shown that one's first contacts during teaching practice come with worries of this nature, and so greater attention should also be focused on them.

\section{2 Seeking partnership}

As already noted in the previous subchapter, students were mainly worried about cooperation with faculty teachers. To some extent, this worry is understandable, and can be transformed into a positive reaction in just a few moments, or instead into finding that the faculty teacher does not do his or her work in line with the student's expectations. This finding was stated by a third of research participants, especially those in preschools. Their responses include a clear seeking for mutual sharing and partnership between student and teacher. Students expect that faculty teachers will always explain their responses calmly. Reality then surprises them.

A girl arrives at preschool crying in the morning. I put her on my lap and we play with a doll. The teacher then berated me saying that if she did that she wouldn't manage it and I shouldn't get children accustomed to it. (SO13)

According to students' subjective perception, the position of faculty teacher is incredibly important. It is shown that it is even more important than the position of the academics who are responsible for teaching practice in the study programmes, and who are meant to provide a certain supervision over teaching practice by the universities.

What I learnt at the faculty was merely theoretical. I need my faculty teacher to understand what is happening in the class. (ZQ39)

Over the course of their practice, students found themselves in situations they assessed as educationally "unclear". These were situations where they were unsure whether they were dealing with the children correctly, and so they wanted to clarify the personal position which they took at that moment. They sought help from the faculty teacher.

I have to go to preschool with a lot of patience, because the girls don't behave at all, they don't follow the rules and they're already 5 years old. I feel that they're excused for a lot of things. I asked the teacher about it, and she told me I shouldn't worry about the parents but rather the essence of a teacher's job is to ensure parents especially are satisfied. (SQ4) 
Many studies have noted problems in children's behaviour, but in this regard the student sought support in academic literature and subsequently wanted to discuss this with the faculty teacher, because she did not understand why the children were behaving in a particular way. It did not fall within their knowledge structures, and so she sought arguments and explanations. She did not get any.

In their responses, students stated that they did not often meet parents. There was an obvious attempt by teachers at leaving students out of this communication. This phenomenon was clear both within preschools and within primary level elementary schools. One can only make educational guesses as to why that was the case. Perhaps the leimotif was teachers' protective instinct, in which they subconsciously wanted to protect their "young colleague" from unpleasantness. On the one hand, it is a good strategy for the school, but on the other hand students also have to try out communication with adults, especially where they spend all day looking after their children. From what they were able to observe, students during teaching practice said that they thought parents were too demanding. They even noted in preschools claims that parents wanted their children to also be educated in preschool. This is somewhat confirmed by Opravilová (2013), who says that in recent years parents increasingly take a more rational and realistic approach to the education of preschool-age children. This is because children are seen as part of the presentation of the family status. Educational activities are offered by preschools in line with this. Students understood this challenge as requiring them to prepare interesting and demanding educational activities.

There were plenty of occasions where teachers said that parents are now very important. Faculty teachers often made this statement even in situations which the students assessed as interesting for explaining to parents. As was shown, however, teachers are also "afraid of parents", and their responses to the students had connotations of warnings in order not to create unnecessary conflict.

We were playing with beans, and suddenly I saw a worm. All I could think of was to show it to the children and explain what it was doing there. But then I got told off that I should hope they don't say it at home, because then there'd be hell. Parents are really demanding here, but I have the feeling that it's only because the teachers aren't able to explain to them properly what they are doing. (SQ10)

As is clear from the example, the student managed her approach well, but the faculty teacher, apparently out of her fear of parents' reactions, was unable to objectively assess her endeavour. Students often stated they had the "feeling that they were more worried about what parents would say than what the children do." All children have a natural ability to learn and become familiar with new things, but they often become mere means of power pressures and fashion trends. Only a teacher who is sure of his or her professional competence can contend with this stress. It would appear that this insecurity is the source of the problems which teachers and parents have, and in our case this has also influenced the student, who felt that she "knows more than the teacher".

Sometimes students are unable to grasp the situation which has arisen from teachers' responses, and experience unnecessary swings in emotion.

I wake up in the morning tired again, but looking forward to the children. We did well yesterday. As soon as I arrive at school I'm angry. We made a book with the kids yesterday and it had been on display. It's not there today. I asked the teacher about it and got nothing. Simply, it wasn't there. I don't understand. The kids were crying. They were sad, and so was I. (SO3) 
The student came up with the idea of a display, and her activity was not positively received by teachers. This led to disappointment. It is notable that students in preschools did not describe problems with the didactic grasp of educational content, or with preparations for their work. One can thus deduce that didactic preparation is not a problem for students of teaching for preschools.

The situation was different for elementary schools, where the students spoke more about didactic difficulties, such as in producing their own preparation for particular teaching periods. It is naturally a challenge for the faculty to ensure didactic reflections are focused on in preparing teachers for primary level elementary schools, which (as research has demonstrated) create a solid basis for managing even unusual professional situations.

For a teaching education, it is important that students feel a mutual partnership between institutions, which is then positively transferred to the student during practice. The challenge remains of finding specific faculty teachers who can be a positive example for students. It is clear that even the best co-operation between organisations cannot guarantee how the specific situations for specific teachers in contact with specific students will be reflected. This, however, is important and an important path towards supporting a starting identity, because when seeking responses to the questions, "Do I want to stay here?", "Do I want to be a teacher?", faculty teachers can provide great assistance. It has been shown that the personal experience of the faculty teacher and his or her personality characteristics are also very important, because they are important for students and also motivating are their own observations, recollections and the presented experience of the faculty teacher, which are expressed outside educational content and are a component of students' social adaptation to the conditions of work in school.

\section{3 Response to children's problems with adaptation}

Adaptation to a new environment is a problem which not only children have to deal with, but also their parents. Even within the context of Czech academic discourse, this is an issue which has been subject to fairly broad research (Opravilová, 2013, Majerčíková, \& Syslová, 2014, Šulová, 2004). A child's transfer to preschool and then to elementary school is one of the major areas in the relationship between family - preschool and elementary school. Co-operation between these institutions is fundamental, including in terms of satisfying children's needs. Children's adaptation to the school environment is a long-term matter and is linked to certain risks at the start of attendance. A child's entry to preschool or elementary school is often influenced by disproportionate motivations in both a positive and negative sense - the idealisation of the preschool or elementary school environment, or in contrast threats from parents. A child's parents may be a source of a negative picture of the school environment through the child receiving information such as: "Just you wait for school, they'll teach you there!" (Šulová, 2004). An important element influencing a child's adaptation is determining the period and frequency of the child's presence in preschool in line with his or her needs and mental state. An important aspect arising from the family environment is the willingness to accept advice and help from the preschool teacher and make use of activities which the preschool offers to parents for facilitating the child's adaptation. As our research has shown, the child's adaptation, response of the child, parents and teachers, has become an important situation for the students on practice. Their responses refer to the emotional symptoms of the short-term reality shock (such as "I was heartbroken"). 
New children still miss their mums, they keep on crying and have to be consoled; they are exhausted all morning. The teacher doesn't do much about it and it feels strange to me. (SQ2)

I had a weird morning today. Mareček wouldn't leave his dad. He kept crying and standing at the door. The teacher told me he sometimes stands there all morning. I asked what I should do. The response - nothing. Just leave it. (SQ3)

I woke up with a headache so I hope the kids aren't going to cry so much. (SO7)

The students were also surprised by the children's morning reaction because according to the teachers' assertions, the children should have already been adapted. But every child manages their adaptation differently, and so the actual process takes place at various rates and over various timespans. Parents' behaviour during their child's adaptation is also important. Parents also have to deal with the new situation. They should by supported by the teacher.

There are also problems with children's adaptation upon transfer to the first year of elementary school. We can currently observe a kind of increased preparation for elementary school in preschools, because education is compulsory in the Czech Republic now from 5 years of age. It is also interesting to observe the mutual reactions of teachers at preschool and elementary schools, who appear to seeking excuses for their failures.

I was surprised by the teacher, who kept asking what the kids learnt at preschool since they knew nothing. (Z 43)

Mutual co-operation between preschool and elementary schools is a phenomenon which needs to be focused on more. It would be interesting to map better the reasons which lead to teachers pointing fingers at each other, and which preschools also do towards parents. It is as if they are seeking reasons for emphasising their own importance.

Primary level elementary school teachers also often complain about their colleagues at senior level who tactlessly ask what they taught them at primary level. This study's authors found this to be prevalent when visiting the schools where students' teaching practice occurs. This fact also deserves attention from researchers. It is obvious that even primary-level teachers at elementary schools experience questioning of their professionalism and position at their schools. This may also be a reason for their attitude towards teachers at preschools.

In this regard, the faculty securing practice can play an important role. In the process of professionalization of a future teacher, it is important that they believe in the meaning and importance of their profession. An example of good practice could be seeking bridges between preschool teachers and primary-level teachers at elementary schools, such as through academic debate which could take place at the faculty. This model has been verified at the workplace where the study authors work.

\section{4 Teacher as nurse}

Faculties preparing future teachers know that there are situations which they cannot get an active handle on and clarify to students adequately during the course of theoretical preparation. They can provide theoretical foundations, but they cannot demonstrate certain phenomena merely through academic writings. These phenomena include the issue of children's healthcare. Although recently curricula have included subjects reflecting child sickness, students can hardly imagine how such illnesses may impact the teacher's teaching activities. Even at a theoretical level, not enough focus is given to these issues, and perhaps this may be one reason why students coming to their teaching 
practice are not equipped with a sufficient range of information which could help them ascertain or explain the particular phenomenon and then to analyse it. When medical issues come up during practice, all teaching activities take a back seat and the teacher has to deal with the acute situation which has occurred. Students have seen this during their practice.

I'm taking the phone. A mum called saying she's leaving Barunka at home because she has diarrhoea, but her husband will bring their second daughter. In half an hour, the second girl also has diarrhoea and one boy has been vomiting. It looks more like a hospital than a preschool here today. I have to chase up parents all day asking them to come and pick up their kids.( SO12)

I really didn't want to get up this morning, but duty calls. First thing, I find out that one girl in the class has nits. SO2)

As can be seen from the responses, real life at school results in situations which even the best university cannot prepare its students for. Even if students study paediatric preparation, first aid and the foundations of child biology during their undergraduate lessons, it appears they would also need to be equipped with practical advice. Injuries are frequent in preschool, and students need to respond appropriately.

A boy I didn't have my eye on fell in the garden. I had to explain what happened to his parents. I managed okay, but it made me sick to the stomach. I had expected help, but I didn't get any.( SQ6)

This student's feelings of personal remorse, also somatically supported (stomach pain) were evidence that the student was suffering and feared for the boy and the reaction of his parents, and in this situation naturally sought support. She expected help, or another strategy from the faculty teacher for her practice.

We are witness at schools when meeting faculty teachers that they do not have time for other work when dealing with children's health problems. Teachers evaluate these issues as parental failure. In this regard, faculties could also play an important role in seeking a suitable space for professional discussion between the parents and faculty teachers, and invite the students to these debates. An example of good practice of how to deal with health issues is the project, Od začátečníka k mentorovi, or From Beginner to Mentor (2014-2016), which was implemented at the workplace where the authors work, and one of whose outcomes was the production of methodical guidance for teachers and students who find themselves with a sick child yet want to continue to undertake teaching activities.

\section{5 Fatigue as a strong experience of students doing practice}

The final days of teaching practice provide fascinating and emotionally charged testimony from students. It is clear that the end of teaching practice was the strongest moment, and this is also reflected in the data.

For some students, they experienced short-term reality shock. Reality shock can be manifested in terms of somatics (fatigue, headache), emotions (mood change, disillusion, sadness) or cognition (insecurity, doubting one's way of working). Short-term reality shock can result in work disillusion and the student deciding not to actually become a teacher (Roy \& Robichaud, 2016). From analysing diaries, it is clear that short-term reality shock was identified in both somatic and emotional fields..

I spent my final two days at the end of my tether. I had an incredible headache, and I was generally exhausted. (SQ15) 
In the somatic field, there were headaches, fatigue and general exhaustion. These manifestations also led to a loss of students' energy and performance quality.

I couldn't handle it psychologically any more, and I was crying even during games. I was so physically and mentally exhausted that I needed to compose myself.

After that, for a while I considered giving up on the preschool teacher profession because it isn't worth it. (SQ11)

In terms of psychology, manifestations such as crying, shouting, anger, nervousness were described. From the testimony of one student, it is clear that her state led her to doubt herself and her own professional identity.

I feel disappointed and sad. I've got a headache, but I'll get through it somehow. (Z4) For research participants, the diaries became an aid and to some extent also a therapeutic tool. Students stated that they often went back over their entries and sought support in their response to situations they found themselves in.

The diary has helped me. I couldn't rely on the teacher, so at least I got it off my chest. (SO21)

The participants' diaries thus also served as a therapeutic.

\section{Conclusion}

In implementing their intentions, all students find themselves in situations where they have to take a stance. Through these interactions, they create their own mental construct which puts into context the experience they acquired from what they went through. The insight isn't about reality, but about its importance for the student. On the basis of the teaching practice they experienced, and lived through, the student evaluates their theoretical knowledge and puts it into context. The direct transmission of complete knowledge is impossible. Students create their own meaning for words, ideas and experience on the basis of their actions. This is one reason why teaching practice is of fundamental importance to every student.

In the introduction, we have already declared that this study presents the more extreme testimony of students describing their personal experience, something the authors perceive as an important foundation for influencing the starting identity of the future teacher. Within the research, students' resilience was not monitored, although this can be considered in the next phase of research, and these findings can be used for data comparison.

The research showed that the person who accompanies him or her on the imaginary frontiers of reality, i.e. the faculty teacher, is of fundamental importance to the student at his or her practice. Students seek a partner and advisor in the faculty teacher, expecting support from them. They want to discuss academic, practical and administrative matters with them so they can understand the processes taking place within the school. Students want to be in contact with parents, they want to learn how to manage this communication channel and want to get a grasp of different situations through the faculty teacher.

The presented research had some limitations through its focus. Research participants were teaching degree students at only one Moravian university. Only qualitative data was presented, although it does in a sensitive manner point out problematic situations which the student experiences as highly personal. The research results, however, relate only to a specific finding, even though some data and its interpretation may have a broader connotation and overlap. Thus there is potential for further research.

The interim results of the research imply that we should not neglect students' teaching practice and their personal experience of this, which can also influence changes in 
teaching-focused programmes. It has been demonstrated, for example, that in schools today attention needs to be paid to various types of child sickness which teaching students are unable to deal with unless they know about them.

Faculty schools should become an integral component of students' lives during the course of their studies, beginning in the first year. Faculty teachers need to be thoroughly prepared for their position of working with students. Here, we can implement and subsequently verify a so-called open school model, in which the university plays the role of co-operating partner. As the participants' testimony makes clear, it is not enough that they are warned of possible problems during their theory lessons at university. It is also essential that they encounter the real environment in which they may be working during the course of their studies, during their professional beginning. It is important that they have the opportunity to get a grasp and an emotional feel for what preschool and elementary schools are as an institution. This will also support their professional identity.

\section{References}

Bunnin, N., (ed). (2004). "Lived experience". The Blackwell Dictionary of Western Philosophy. Blackwell Publishing.

Dicke, T., Elling, J., Schmeck, A., \& Leutner, D. (2015). Reducing reality shock: The effects of classroom management skills training on beginning teachers. Teaching and Teacher Education, 48, 1-12.

Feldt, R. C. et al. (2011). Measurement adjustment to college: Construct validity of the Student Adaptation to College Questionnaire. Measurement and Evaluation in Counseling and Development, 44(2), 92-04.

Gavora, P. (2002). Rozhodnutie stat' sa učitelom. Pohl'ad kvalitatívneho výskumu. Pedagogická revue, 54(3), 241-256.

Hejlová, H., Opravilová, E., Uhlířová, J., \& Bravená, N. (2013) Nahlížení do světa dětí. Praha: Univerzita Karlova.

Chang, E.C., Sanna, L., Riley, M. M., Thornburg, A. M.,Zumberg, K. M., \& Edwards, M. C. (2007). Relation between problemsolving styles and psychological adjustment in young adults: Is stress a mediating variable? Personality and Individual Differences, 42(1), 135-144.

Janík, T. et al. (2002). Úloha fakultního cvičného učitele a fakultní cvičné školy v př́pravě budoucího učitele. Brno: MSD.

Kim, H. \& Cho, Y. (2014). Pre-service teachers' motivation, sense of teaching efficacy, and expectation of reality shock. Asia-Pacific Journal of Teacher Education, 42(1), 67-81.

Korthagen, F. A. J., Kessels, J., Koster, B., Lagerwerf, B., \& Wubbels, T. (2011) Jak spojit praxi s teorií: Didaktika realistického vzdělávání učitelů. Brno: Paido.

Lindseth, A.,\& Norberg, A (2004). A phenomenological hermeneutical method for researching lived experience". Scandinavian Journal of Caring Sciences. 18(2), 145-153.

Lukášová, H. (2015). Učitelské sebepojetí a jeho zkoumání. Zlín: FHS UTB.

Majerčíková, J., \& Syslová, Z. (2014). Profesní zdatnost učitelek pro spolupráci s rodiči. Situace v českých a slovenských mateřských školách. In Syslová, Z., \& Rodová, V. (eds.), Předškolní vzdělávaní v teorii a praxi (124-135). Brno: MU.

Mareš, J. et al. (1996). Učitelovo pojetí výuky. Brno: CDVU MU.

Mareš, J. (2013). Pedagogická psychologie. Praha: Portál.

Roy, J., \& Robichaud, F. (2016). The shock of reality of new nurses. Recherche en Soins Infirmiers, 127, 82-90.

Spilková, V. et al. (2004). Současné proměny vzdělávání učitelů. Brno: Paido. 
Spilková, V. (2010). Evropské přístupy k pojetí kvality učitele - optikou formálních dokumentů. Pedagogika, 60(3-4), 70-80.

Spilková, V., Tomková, A., Mazáčová, N., \& Kargerová, J. (2015). Klinická škola a její role ve vzdělávání učitelů. Praha: Retida spol. s.r.o.

Stokking, K., Leenders, F., De Jong, J., \& Van Tartwijk, K. (2003). From student to teacher: Reducing practice shock and early dropout in the teaching profession. European Journal of Teacher Education, 26(3), 329-350.

Strouhal, M. (ed.). (2016). Učit se být učitelem. Praha: Univerzita Karlova.

Šulová, L. (2004). Děti nastupují do mateřské školy. Informatorium 3 - 8.

Švaříček, R. (2011). Zlomové události při utváření profesní identity učitele. Pedagogika.sk, 2(4), 247-274.

Wiegerová, A., \& Gavora, P. (2014). Proč chci být učitelkou mateřské školy? Pohled kvalitativního výzkumu. Pedagogická orientace, 24(4), 510-534.

Wiegerová, A. et al. (2015). Profesionalizace učitele mateřské školy z pohledu reformy kurikula. Zlín: FHS UTB.

Wiegerová, A. (2016). The Careers of young Czech University teachers. Zlín: Nakladatelství UTB.

\section{Contacts}

prof. PaedDr. Adriana Wiegerová, Ph.D.

prof. PhDr. Hana Lukášová, CSc.

Tomas Bata University in Zlín

Faculty of Humanities

Štefánikova 5670

76001 Zlín

Czech Republic

wiegerova@utb.cz 